\title{
Bestiality and Gluttony in Theory and Practice in the Comedies of Giovan Battista Della Porta
}

\author{
SERGIUS KODERA
}

University of Vienna

\begin{abstract}
Giovan Battista Della Porta (1535-1615), Neapolitan nobleman, scholar/scientist, and writer famed for books on natural magic and physiognomy, expressed quite explicit views on bestiality - that is, on human beings having sex with animals. Della Porta populated his plays with characters who allude to their desire both to have sex with animals and to assume animal shapes in order to satisfy their yearnings; the gulone (the glutton), an archetypal character that was a cultural relic from Roman comedy, is a case in point. According to Della Porta, eating habits are indicative of other habits that can be expressed in a person's physical appearance; his fascination with monstrous bodies and their concomitant bizarre sexual desires betrays a tendency to understand human beings as akin to animals, and indicates the porosity, as he saw it, of boundaries between these two worlds.
\end{abstract}

Le noble napolitain Giovan Battista Della Porta (1535-1615), chercheur, scientifique et écrivain, connu pour ses ouvrages sur la magie naturelle et la physiognomonie, s'est exprimé de façon explicite au sujet de la bestialité, c'est-à-dire au sujet d'humains ayant des rapports sexuels avec des animaux. Les pièces de théatre de Della Porta sont habitées par de nombreux personnages qui font allusion à la fois à leur désir d'avoir des contacts sexuels avec des animaux, et de prendre une forme animale pour assouvir ces désirs. Le gulone (le glouton) en est un cas, tout en étant un personnage archétypal issu de la comédie romaine. D'après Della Porta, le comportement à table pouvait indiquer la présence d'autres habitudes, parfois visibles dans laspect physique d'une personne. Sa fascination pour les corps monstrueux et leurs désirs sexuels étranges trahit sa tendance à considérer les humains comme apparentés aux animaux, et met en lumière la perméabilité telle qu'il la concevait de la limite entre ces deux règnes.

\section{Introduction}

$\mathrm{T}$ his article investigates early modern Italian discourses on bestiality, here understood in the modern sense of the word, that is, human beings having sex with animals. ${ }^{1}$ From the twelfth century, bestiality was commonly considered a most abominable crime against nature: there was a widespread belief that intercourse between people and animals would lead to the procreation of

1. I wish to thank the editors as well as four anonymous reviewers for their many important suggestions; all errors, of course, are mine.

Renaissance and Reformation / Renaissance et Réforme 38.4, Fall / automne 2015 
monstrous animals that were half man and half beast. ${ }^{2}$ This belief indicates a fear of the porousness of boundaries between animals and human beings, which in turn raises interesting questions - and worries-about the malleable nature of the individual human body; increasingly, therefore, bestiality appeared in the courts. ${ }^{3}$ Giovan Battista Della Porta (1535-1615), a Neapolitan nobleman, scholar/scientist, and writer famous for his books on all varieties of natural magic and physiognomy, expressed quite explicit views on these early modern discourses of the body. ${ }^{4}$ Della Porta not only subscribed to the idea that human beings and animals may crossbreed; he also gave detailed instructions on how to produce monstrous offspring, which was widely considered as a portentous and marvellous event.

In their Wonders and the Order of Nature, Lorraine Daston and Katherine Park have outlined Della Porta's deep interest in the marvellous and the demonic arts. ${ }^{5}$ Della Porta belonged to an influential group of what Daston and Park have labelled "preternatural philosophers."6 In this tradition, Della Porta developed a "sublime science" that catered to a courtly environment in which "wonder became a reflection not of ignorance but of virtuosity and connois-

2. For short but succinct introductions to the topic, see Jonas Liliequist, "Peasants against Nature: Crossing the Boundaries between Man and Animal in Seventeenth- and Eighteenth-Century Sweden," Journal of the History of Sexuality 1.3 (1991): 397; Mia Korpiola, "Rethinking Incest and Heinous Sexual Crime: Changing Boundaries of Secular and Ecclesiastical Jurisdiction in Late Medieval Sweden," in Boundaries of the Law: Geography, Gender, and Jurisdiction in Medieval and Early Modern Europe, ed. Anthony Musson (Aldershot: Ashgate, 2005), 108-10; Joyce E. Salisbury, The Beast Within: Animals in the Middle Ages (New York: Routledge, 1994), 83-85.

3. Salisbury, 100-01, says that from the fifteenth century onward, bestiality became a crime, and that we see a rising number of trials. As a result, "it became increasingly difficult to assess the difference between humans and animals." See also Salisbury, 138-39.

4. For a short but succinct biography, see Giovanna Romei, “Della Porta, Giovambattista," in Dizionario biografico degli Italiani, ed. Vincenzo Capelletti, vol. 37 (Rome: Istituto Della Enciclopedia Italiana, 1989), 170-82. Paolo Piccari's Giovan Battista Della Porta. Il filosofo, il retore, lo scienziato (Milan: Franco Angeli, 2007) is a general introduction.

5. Lorraine Daston and Katharine Park, Wonders and the Order of Nature, 1150-1750 (New York: Zone Books, 1998), 160: “The objects of preternatural philosophy coincided with the traditional canon of marvels. They included both the results of occult action such as magnetic attraction and the reputed power of the amethyst to repel hail [...] and rare individual phenomena, such as bearded grape vines, celestial apparitions, and rains of frogs and blood." Daston and Park, 162: "Demonology was in some ways the alter ego of preternatural philosophy, for demons also worked marvels."

6. Daston and Park, 159-64. 
seurship; the product not only of great experience and erudition, but also of impeccable taste." In tune with this penchant for the marvellous, Della Porta populated his various plays with characters who allude to their desire both to have sex with animals and to assume animal shapes in order to satisfy their yearnings.

In Della Porta's plays, it is the persona of the gulone (the glutton), an archetypal character that was a cultural relic from Roman comedy, who becomes a grotesque embodiment of the desire to have sex with animals. ${ }^{8}$ The glutton is someone who suffers from an insatiable appetite for both food and drink, and is thus always keen to obtain the proverbial "free lunch" at other people's tables. In Della Porta's time, such excessive cravings for food were commonly associated with illicit sexual behaviour. 9 As Joan Salisbury writes, "by the late Middle Ages, it seems that one's claim to humanity could be more and more easily lost. By sins of the flesh (food and sex) one's offspring could slip over the line from human to beast." 10 The glutton therefore embodied a characteristic behaviour that fitted well into Della Porta's comedies, which generally display a large repertory of highly grotesque and potentially subversive imagery. This imagery accretes in a series of kaleidoscopic images of both food and sex that are explored in the following pages.

\section{Della Porta's theatre}

Della Porta was a highly prolific author for the stage; of the thirty-one comedies attributed to him, fourteen (and three tragedies) have survived, some of them

\section{Daston and Park, 170 .}

8. For a very good introduction to Della Porta's gulone, see Donald Beecher and Bruno Ferraro, "Introduction," in Giovan Battista Della Porta, The Sister [La sorella], trans. with introduction and notes by Donald Beecher and Bruno Ferraro (Ottawa: Dovehouse, 2000), 46-50. Hereafter cited as Sister or Sorella depending on language version.

9. On the connections among food, illicit sex, and debauchery see also Tessa Storey, "Courtesan Culture: Manhood, Honour and Sociability," in Erotic Cultures of Renaissance Italy, ed. Sara F. Matthews-Grieco (Farnham: Ashgate, 2010), 250-51; Allen J. Grieco, "From Roosters to Cocks: Italian Renaissance Fowl and Sexuality," in Erotic Cultures of Renaissance Italy, above, 120-23; the contribution of Marlen BidwellSteiner in this special issue of Renaissance and Reformation.

10. Salisbury, 146. 
considered to be important mannerist texts. ${ }^{11}$ One of the reasons he could be so productive is the fact that his plots are made up of a set of stock scenes. ${ }^{12}$ Della Porta ordered these "theatregrams," to use Louise George Clubb's term, in a kaleidoscopic array - as in a picture gallery_slightly modifying set dialogues in order to fit them to various different plots. ${ }^{13}$ With this in mind, I believe it is legitimate to quote several gluttons from six different comedies by Della Porta without paying undue attention to the specific plots and settings of these plays. ${ }^{14}$

11. For what is still the best introduction to Della Porta's theatre, see Louise George Clubb, Giambattista Della Porta, Dramatist (Princeton, NJ: Princeton University Press, 1964). See also Raffaele Sirri, L'attività teatrale di G. B. Della Porta (Naples: Libreria De Simone, 1968) and the more recent, succinct introduction to the problems of Della Porta's theatre in Raffaele Sirri, "Teatralità del teatro di G. B. Della Porta," in Ledizione nazionale del teatro e l'opera di G.B. Della Porta. Atti del convegno Salerno 23 maggio 2002, ed. Milena Montanile (Pisa: Istituti editoriali e poligrafici internazionali, 2004), 69-82. Della Porta's plays were in all probability written not for a large public but for private audiences. Of the thirty-one comedies that were presumably authored by Della Porta, only fourteen have survived, along with three tragedies (Sirri, “Teatralità del teatro," 69). These are published in the Edizione Nazionale delle opere Giovan Battista Della Porta, vol. 15 [in 4 vols.] under the title Giovan Battista Della Porta, Teatro, ed. Raffaele Sirri (Naples: Edizione Scientifica Italiana, 2000-03) hereafter cited as Teatro. Beecher and Ferraro, 25 and 53, have rightly characterized Della Porta's plays, which were written and published during the last third of the sixteenth and the first decades of the seventeenth century, as "exercises in Counter-Reformation ideology," a statement which is all the more remarkable in light of this essay's topic. For a succinct summary of all of Della Porta's plays, see Clubb, Giambattista Della Porta, Dramatist, 70-242. For a list of tentative dates of their composition, see Clubb, Giambattista Della Porta, Dramatist, 300-01. Many of Della Porta's intricate ruses are echoed in Shakespeare's comedies, such as Twelfth Night and The Merry Wives of Windsor. On these connections, see the summative remarks in Louise George Clubb, "Nicht durch das Wort allein. Jenseits der Sprache von Della Portas Theater," Morgen-Glantz. Zeitschrift der Chrisitian Knorr von Rosenroth-Gesellschaft 18 (2008): 174-77.

12. See the interesting remarks on the connections between Della Porta's art of memory and the stage in Lina Bolzoni, The Gallery of Memory: Literary and Iconographic Models in the Age of the Printing Press, trans. Jeremy Parzen (Toronto: University of Toronto Press, 2001), 163-69.

13. Louise George Clubb, "Theatregrams," in Comparative Critical Approaches to Renaissance Comedy, ed. Donald Beecher and Massimo Ciavolella (Ottawa: Dovehouse, 1986), 15-34.

14. Della Porta's comedies are over before night falls, and (sometimes even against the will of their protagonists) they end with marriage-the only alternatives being death or emigration. Transgression on the lovers' part occurs only on the surface-as a dream or momentary disturbance of an otherwise static social order. See Michele Rak, "Modelli e macchine del sapere nel teatro di Giovan Battista Della Porta," in Giovan Battista Della Porta nell' Europa del suo tempo, ed. Maurizio Torrini (Naples: Guida, 1990), 409-10, and Clubb, "Nicht durch das Wort," 181. 
The settings of Della Porta's comedies are well in tune with his general strategy as a dramatist: most of his comedies are structured by peripety-a sudden and unexpected intervention-even though his happy endings are always the result of natural causes (usually the timely return of a family member missing for decades and hence believed dead) ${ }^{15}$ His labyrinthine plots thus appear hopelessly frustrating until they are suddenly resolved by a final peripety: a coup de théatre with unexpected and satisfying dramatic impact that produces order out of chaos and a happy resolution all around. ${ }^{16}$

Unfortunately, we cannot date Della Porta's comedies exactly. He probably started writing them early in his career, so that some would have been written in the 1550s and 1560s, before the end of the Council of Trent-that is, in an era when freedom of speech was less restricted than it was during the last decades of the sixteenth century. There seems to me to be some evidence that Della Porta's comedies circulated-dangerously, in all probability, for Della Porta-in manuscript versions that were much more explicit than those that appeared later in print and which nonetheless contain a lot of very explicit sexual language. Trappolaria, a carnival play, is an interesting text in this respect. Raffaele Sirri, its modern editor, has published an extensive list of omissions and changes present in the first printed edition of 1596. The expurgations and emendations remove or modify even the most remote allusions to religious topics or imagery: crowns, the cross, biblical figures, the devil, fortuna, and destiny. God's name had to be entirely absent from the stage: even colloquialisms such as Oh dio or A dio ("Oh God!" or "To God!") were unacceptable. ${ }^{17}$ These editorial interventions are indicative of a narrowing of the intellectual climate in the period following the Council of Trent. ${ }^{18}$

That being said, highly explicit passages sometimes-temporarily-escaped censorship. A case in point is the pimp's hymn to the vagina (the reina di fessa) in Trappolaria that appears in the first printed edition (Bergamo, 1596) but was subsequently omitted in the Venetian edition (1597) and in three later

15. Beecher and Ferraro, 25 and 30.

16. Giovan Battista Della Porta, Gli duoi fratelli rivali: The two rival brothers, ed. and trans. Louise George Clubb (Berkeley: University of California Press, 1980), 9, hereafter cited as Rivali.

17. Teatro, 2:221-22.

18. See, for instance, Giovanni Romeo, L'inquisizione nell'Italia moderna (Bari: Laterza, 2002), 58 on the censorship that caused the impoverishment and increasing isolation of Italian culture in a European context. 
editions. ${ }^{19}$ Another example from Trappolaria that completely escaped the censors is a passage that recounts the practice of sodomy among soldiers (4.1): the pimp Lucrino asks the simpleton soldier's servant Leonetto how many times he had been raped by his Capitano and how he had adapted to the increasing sizes of penises he was forced to accommodate. ${ }^{20}$ At the same time, Lucretio Nuccio (who had commissioned the 1604 edition of Sorella) wrote that he was publishing the text against the wishes of the author, who claimed that he disliked these versions and that the editions of La Furiosa, Lo Astrologo, and La Turca that were to follow were all "disperse, scorrette e mal trattate" ("scattered, incorrect, and mistreated"). ${ }^{21}$ This could well suggest that Della Porta was actually keen to publish less offensive versions of his plays so as to clear himself of the suspicion that he had written highly salacious texts, an act that would have been damaging for him in the eyes of the increasingly aggressive Inquisition. Carbonaria (1606) makes the same point in the prologue when the author says "Non sapete che le comedie son scherzi de suoi studi più gravi e che non ha bisongo delle lodi delle comedie?"22 ("Don't you know that comedies are jokes of his more serious studies and that he has no need of praise for his comedies?")

\section{Physiognomonics and the monstrous}

In any case, Della Porta's theatre, with its many grotesque figures, echoes and synthesizes a distinctly naturalist agenda that was pursued by the author in his highly popular and ostensibly erudite books on natural magic and human physiognomy. The artful production of monsters by crossbreeding was one of the most spectacular ways in which Della Porta demonstrates his miraculous ability to influence and manipulate other bodies; crossbreeding also served to confirm that his magic was natural (as opposed to demonic) and that his physiognomy was founded on true principles. ${ }^{23}$

19. Trappolaria, act 3, scene 6 (Teatro, 3:279). See also Romeo, 220-22 for remarks on the censorship of this passage.

20. Trappolaria, 4.1 (Teatro, 2:287).

21. Teatro, 3:117-18, my translation: cf. Della Porta, Sister, 153n3.

22. Carbonaria, Prologo (Teatro, 2:452, my translation).

23. Giovan Battista Della Porta, Magia naturalis libri XX. (Rouen: Johannes Berthelin, 1650), 58-65. Sergius Kodera, "Humans as Animals in Giovan Battista della Porta's scienza," Zeitsprünge 17 (2013): 414-32. 
Physiognomonics, in Della Porta's terms, was a proto-/pseudo-science on the rise in the sixteenth century. Practitioners saw it as drawing upon the universal visible affinities or likenesses of all created things, from plants and animals to the bodies and faces of human beings and, even farther up the ontological scale, to the appearance of the planets. New books on this ancient art, filled with hundreds of illustrations (thanks to print technology) and bearing titles such as De humana physiognomonia or De coelestis physiognomonia, sometimes saw many editions but might also circulate only in manuscript to be rediscovered centuries later-like Della Porta's Metoposcopia (The Art of Reading Signs in the Human Face) ${ }^{24}$ Others of his works were only published long after Della Porta's death, as was the case with Chirophysiognomia (The Art of Reading Palms). ${ }^{25}$

Della Porta's physiognomonics is an art that produces cartographies of the outward appearance of physical bodies, thus predicting hidden inclinations or dispositions of the soul within (past, present, or future) with the intention of curing all manner of physical diseases. The massive effort Della Porta made to map the exterior appearances of all animated bodies occurred in tandem with what we know today to be a more scientific approach towards cartographies of human bodies (as well as landscapes), most notably in Andrea Vesalius's (1514-64) anatomies, which were at the time revolutionizing the world of medicine. ${ }^{26}$ The Coelestis physiognomonia emphasizes the veracity of the physi-

24. Giovan Battista Della Porta, Metoposcopia, ed. Giovanni Aquilecchia (Naples: Istituto Suor Orsola Benincasa, 1990).

25. Giovan Battista Della Porta, De ea naturalis physiognomoniae parte quae ad manuum lineas spectat. Chirophysiognomia, ed. Oreste Trabucco (Naples: Edizioni scientifiche Italiane, 2003); Flavio Caroli, in Storia della fisionomica, arte e psicologia da Leonardo a Freud (Milan: Leonardo, 1995), gives a sound historical introduction; Claudia Schmölders, in Das Vorurteil im Leibe. Eine Einführung in die Physiognomik (Berlin: Akademie, 1995), has a stimulating philosophical approach to the topic. On Della Porta's physiognomonics, see Ulrich Reisser, Physiognomik und Ausdruckstheorie der Renaissance, der Einfluss charakterologischer Lehren auf Kunst und Kunsttheorie des 15. und 16. Jahrhunderts (Munich: Scaneg, 1997), 89-93.

26. The literature on Vesalius is vast: see Barbara Maria Stafford, Body Criticism: Imaging the Unseen in Enlightenment Art and Medicine (Cambridge, MA: MIT Press, 1992) for a stimulating attempt to relate these cartographies to novel techniques of image reproduction (such as etchings) and to efforts towards a new schematization in science (such as Ramism). For a biography of Vesalius, see C. D. O'Malley, Andreas Vesalius of Brussels 1514-64 (Berkeley, CA: University of California Press, 1964). On the interesting topic of variation in individual and standardized human anatomies in Vesalius, see Nancy 
ognomonic discipline, asserting that by employing its methods one is able to judge the future of any person with a single glance (all'improvviso). ${ }^{27}$ Viewed from inside the field of its practitioners and theorists, physiognomonics is as rational a science as anatomy because both can be used as universal descriptors. ${ }^{28}$ According to the circular reasoning that is characteristic of physiognomonics, a monstrous body, or even the mere wish to have an abnormal body, betrayed hidden monstrous inclinations. It goes without saying that the persona of the glutton, whose body Della Porta describes as extremely deformed and, as we shall see in a moment, driven by cravings for illicit sex, is a perfect case in point.

\section{The glutton as sodomite}

For contemporary audiences the glutton must have served as a reminder not only of popular tales about a paradise in which food was over-abundant, but also-and conversely-of the images of famished bodies that were deeply ingrained into early modern minds. ${ }^{29}$ Donald Beecher and Bruno Ferraro have characterized the glutton on Della Porta's stage as a caricature of a new type of

G. Siraisi, "Vesalius and Human Diversity in De humana corporis fabrica," Journal of the Warburg and Courtauld Institutes 57 (1994): 60-88.

27. Giovan Battista Della Porta, Coelestis physiognomonia. Della celeste fisionomia, ed. Alfonso Paolella. Edizione nazionale delle opere di Giovan Battista Della Porta, vol. 8. (Naples: Edizioni scientifiche italiane, 1996), 191: “[...] in questa arte che dal solo aspetto, all'improvviso, tanto veracemente predicava le morti, i pericoli della vita e i tempi de gli eventi."

28. For a good commentary on the circularity of his kind of reasoning, see Gérard Simon, "Porta, la physiognomie et la magie, les circularités de la similitude," in La magie et ses langages, ed. Margaret Jones-Davis (Lille: Université de Lille III, 1980), 101-02: “C'est là ou on touche la zone aveugle de cette pensée fondée sur les similitudes. En apparence-pour elle-même elle est remarquablement vigilante, à l'affût du moindre indice. En réalité, elle se trouve toujours en position de redoublement du déjà dit, du déjà écrit, du déjà vu. Car elle ne fait que thématiser, que porter à l'explicite, une pratique partiellement ignorante d’elle-même et qui fondait spontanément ses inférences sur les qualités sensibles et leur patiente comparaison. Que l'on songe ici à la description qu'a donnée Lévi-Strauss de la pensée sauvage, et qui s'applique de si près à la connaissance que prenait des simples l'Europe paysanne."

29. On the paese di Cuccagna as the paradise in which dreams of affluence and of life without toil become true, as well as this idealized place's role in popular Italian culture, see Carlo Ginzburg, The Cheese and the Worms: The Cosmos of a Sixteenth Century Miller, trans. John and Anne Tedeschi (Baltimore: Johns Hopkins University Press, 1980), 82-83 and 162-63 with references; Piero Camporesi, The Land of Hunger, trans. Tania Croft-Murray et al. (Cambridge, MA: Polity Press, 1996), 52-79. 
princely Italian gourmet. ${ }^{30}$ As Michele Rak has argued, in these comedies the glutton functions as a grotesque reflection of the fear of starving: no matter how refined or expensive the cuisine, everyone eating on Della Porta's stage was on the verge of starvation. ${ }^{31}$ In fact, the glutton is characteristically hailed as a morto di fame (a starvelling-literally, someone "dying of hunger"). ${ }^{32}$ The average glutton is not only a voracious eater and drinker, however: he is a sexual pervert, too. Panfago ("Eat-all")-the parassita (an archetypical character distinguished by his freeloader tendencies and his role in early modern Italian theatre as a buffoon) in the Carbonaria (written after 1591, published 1606)describes the nature of his own appetites as follows:

Even so [in spite of all adversities] from afar I have made love to a fat little pig that was roasting; she was poking fun at me, because she looked at me with such staring eyes, and her tongue was hanging out from her teeth: I lost my eyes in her, and she pulled out my heart with a hammer, the traitoress: $[\ldots]$ and if my hope fails me, I will go mad with hunger.

Pur, di lontano, ho fatto l'amor con una porchetta grassa che si rostiva; si burlava di me, perché mi mirava con certi occhi stralunati e con la lingua pendente fuori tra' denti: ci ho lasciati gli occhi sopra, e mi ha cavato il

\footnotetext{
30. Beecher and Ferraro, 48-49: "Clearly these references to food, accoutrements, and the refinements of the table were a source of audience amusement, at once a measure of pretension, aspiration and excess. The evolving state of Italian cuisine rises to the level of a topos in the play. It is, in fact, not entirely beside the point to align this character with changing social and culinary fashions in the aristocratic and mercantile households of Italy in general. Emulation and imitation were everywhere at play in matters of the table. Thus while we may laugh at the parasite for his excesses, he was, nevertheless, a maker and arbiter of fashions. [...] There was an increase in the variety of dishes, with greater attention given to the preparation of fruits and vegetables, pastries, soups, patés, and pasta. In that regard Gulone's taste for heavy roasts, salamis, and game dishes remains more medieval than cinquecento. But his interest in a well-appointed table with a degree of fantasy in the presentation is modern." See also Clubb's remarks in her introduction to Rivali, 20, where she conceptualizes the glutton's language as the "counter-poetry of materialism."

31. Rak, 406; Camporesi, 78-79. For gruesome descriptions of the blemished bodies of the poor in early modern Italy, see Camporesi, chapter 5. For a false eulogy of gluttony as the pinnacle of all sciences in Pulci's Morgante, see Camporesi, 40-42.
}

32. See also Rivali, 20. 
cuor di martello, la traditora. [...] e se la speranza mi fallisce, arrabbiarò di fame. (Carbonaria, 2.1 in Teatro, 2: 474. My translation.)

Panfago's desire for meat (one is tempted to write "flesh") is here articulated in erotic language that evidences Della Porta's taste for the macabre and for the grotesque: ${ }^{33}$ the words in which the parassita expresses his insatiable desire for food are, in fact, a grim parody of the vocabulary of Petrarch's love lyrics. ${ }^{34}$ Panfago is actually a grotesque embodiment of an anti-idealistic discourse that ridicules the doctrine of the uplifting powers of a spiritual Eros-an immensely influential ideology in the many idealistic literary discourses of Della Porta's day. ${ }^{35}$ When viewed from the perspective of Renaissance Platonic treatises on the virtues of spiritual love and its triumph over carnal desire, this representation of the glutton's monstrous appetite as unequivocally driven by desire for the bestial seems even more monstrous. ${ }^{36}$ Panfago articulates his desire for food and drink not only as a wish to have sex with an animal; he also craves to devour, literally, the object of his desire. Nor is this the only instance in Della Porta where a glutton expresses his longings for this kind of bestiality.

33. See also Sirri, Lattività teatrale, 161-66 and 167-71 for a comparison to other contemporary mannerist and grotesque baroque literature. But see also the remarks in Aristotle's Poetics, 4, 1448b 9-12, on the pleasure of viewing representations of monsters and repulsive animals simply because they are representations and one can learn from them. On the topic, see Paolo Butti de Lima, Il piacere delle immagini. Un tema aristotelico nella riflessione moderna sull'arte (Florence: Olschki, 2012), 4-5 and passim.

34. See Arnaldo Di Benedetto, "Un'introduzione al petrarchismo cinquecentesco," Italica 83.2 (2006): 170-215 and Sergius Kodera "Giambattista Della Porta’s Histrionic Science," California Italian Studies 3 (2012): 8 .

35. See, for instance Marsilio Ficino, Commentaire sur le Banquet de Platon Marsile Ficin. De amore, ed. and trans. Raymond Marcel (Paris: Belles Lettres, 1956), 213-15 (lib. 6, cap. 9). The literature on the subject of platonic love is vast; for introductions, see John Charles Nelson, Renaissance Theory of Love: The Context of Giordano Bruno's Eroici Furori (New York: Columbia University Press, 1958); Michael J. B. Allen, The Platonism of Marsilio Ficino: A Study of his Phaedrus Commentary, Its Sources and Genesis (Berkeley: University of California Press, 1984); Sabrina Ebbersmeyer, Sinnlichkeit und Vernunft. Studien zur Rezeption und Transformation der Liebestheorie Platons in der Renaissance (Munich: Fink, 2002).

36. On the crime of sodomy, see Gregory the Great, Moralia, in Patrologia Latina (1844-64), vol. 75, col. 786 B (lib. 7. cap. 28 V. 18, 36). Because of its sacrilegious nature, Thomas Aquinas includes sodomitical sex acts between different species (sodomiticum vitium) among the worst sins; see the discussion in Michael Carden, Sodomy: A History of a Christian Biblical Myth (London: Equinox, 2004), 183-85. 
In the Tabernaria (written before 1610, published 1616), Lardone ("Big-Lard") wails like a desperate innamorato:

How can I withdraw, when these pork skewers keep me enchained; and how can I keep my eyes off these salami and poultry? Let me make love [to them] a little longer.

Come posso partirmi se queste porchette infilzate mi tengono incatenato, né posso distaccar la vista da questi salami, pollami? Lasciatemi fare un altro poco l'amore. (Tabernaria, 2.4 in Teatro, 4:297. My translation.)

Lardone receives the following answer: "Galante inamorato! Altri amoreggia con le donne, egli con li animali morti." ("What a gallant lover! Others make love to women, he to dead animals!" ${ }^{37}$ This mockery directly points out the bestial and even necrophilic inclinations of this parassita. Nor was this association uncommon: in early modern discourses on the vices, a glutton's greed for food is generally associated with illicit and forbidden forms of sex. ${ }^{38}$ Della Porta's Fratelli Rivali (written after 1591, published 1601) stages the link between the greed for food and the refusal to lead a heterosexual life even more explicitly, as the glutton here declines to seduce a maidservant with the following words:

I'd hang myself first. I've never made love except with suckling pigs and veals; and the worst of it is, she's an ape and yet claims to be a beauty. (Rivali, 169) $)^{39}$

Più tosto m'appicherei; mai feci l'amor se non con porchette e vitelle; ed è il peggio ch'è una simia, e pretende esser belissima. (Rivali, 3.2, 168)

37. Tabernaria, 2.4 (Teatro, 4: 298, my translation).

38. On the connection between gluttony and crimes of lussuria, among them sodomy in general, see Guido Panico, Il carnefice e la piazza. Crudeltà di stato e violenza popolare a Napoli in età moderna (Naples: Edizioni Scientifiche Italiane, 1985), 60-61.

39. For the maidservant's witty retorts, (she calls the glutton a goat, a traditional epithet for a cuckolded husband) see Panico, Il carnefice. Her comments are perhaps meant to slightly defuse the overtly sodomite context. 
Later in the play, the maidservant counters the glutton's false compliments, asking: "Che ho ciera di vitella, o di porca, che ti vòi innamorar di me?" (Rivali, 3.4, 176; "Does my face look like veal or pork that you want to fall in love with me?" My translation.) The glutton replies with a description of his victim that emphasizes his taste for eating the meat of animals rather than for making love to this (or any other) woman.

You have such fetching little lips, red as prosciutto, a little pouting mouth like a suckling pig's, eyes bright as a goat's, fat little tits like a she-veal's, a rump as plump and round as a pasty capon. In short, there is nothing about you that doesn't whet my appetite; nature was wrong not to make you a nanny goat. (Rivali, 177)

Hai certi labruzzi scarlatini come un prosciutto, una bocchina uscita in fuori com'un porchetto, gli occhi lucenti come una capra, le poppe grassette, come una vitella, le groppe grosse e ritonde come un cappone impastato. In somma non hai cosa che non mi muova l'appetito: ebbe torto la natura non farti una capra. (Rivali, 3.4, 176)

Here the glutton represents the object of his desire as palatable in the truest sense of the word: he fantasizes about turning the woman into a beast whom he subsequently longs to devour. Della Porta thus stages a longing not just for sex with animals but also for cannibalism. Here desire is physical appetite for animals: instead of being fetishized in words, as in Petrarch, in Della Porta the woman's body is represented as tasty meat with attendant misogynist implications that culminate in the idea that women are not only objectified but also not fully human-rather, they are animal. ${ }^{40}$

40. These consequences are perhaps most succinctly summarized in Shakespeare's Othello, when Emilia, Iago's wife, says: "'Tis not a year or two shows us a man / They are all but stomachs, and we all but food: / They eat us hungry, and when they are full, they belch us." (3.2.104-07). On the uses of this feeding metaphor in early English literature see Gordon Williams, A Dictionary of Sexual Language and Imagery in Shakespearean and Stuart Literature, 2 vols. (London: Athlone Press, 1994) 1:472-74. On women as food, see also Salisbury, 156: "I showed how one of the defining functions of animals is to be food. Thus, a syllogism emerges that says if animals are food, and women are food, then women are animals. This association increased from the twelfth century on as literary references linked women to animals." See also Caroline Walker Bynum, Holy Feast and Holy Fast: The Religious Significance of Food to Medieval Women (Berkeley, CA: University of California Press, 1987), 206-08, 260, 269. 
We might wonder how these ideas could possibly have been acceptable to Della Porta's audiences. Leaving aside the author's characteristic taste for the macabre, one answer is certainly that images of people roasting in hell's kitchen constituted an integral part of medieval and early modern religious imagery. ${ }^{41}$ On Della Porta's stage, however, it is the braggart soldier-not necessarily the glutton-who expressly cultivates cannibalistic habits (or at least pretends to do so, because his persona is that of a coward pretending to be a very brave man). ${ }^{42}$

He eats meat half raw and bloody, saying that giants do so and that he wants to accustom himself to devouring human flesh and drinking the blood of his enemies. (Rivali, 95)

Mangia la carne mezza cruda e sanguigna, e dice che così mangiano i giganti, e che vuol assuefarsi a mangiar carne umana, e bersi il sangue de' suoi nemici. (Rivali, 2.2, 94)

One might be inclined to see this as a hyperbolic characterization of the braggart soldier (who is cowardly by definition) within a generally farcical framework. Yet one need only recall Montaigne's discussion of cannibalism among indigenous American peoples in order to realize how large the practice of eating human flesh loomed even for the most sophisticated Renaissance authors. Closer to Della Porta's hometown, the glutton's monstrous appetites also recall some of the darkest aspects of contemporary Neapolitan cultural imagery and practice. During popular uprisings in the Kingdom of Naples, the crimes of notorious sanguisughe (bloodsuckers or leeches), such as tax leviers, were avenged by an enraged mob through various forms of cannibalism. ${ }^{43}$ In the Coelestis

41. To give just one example from a sacra rappresentazione depicting a scene of this kind: "Roasted like suckling pigs / Quartered with consummate care / Stoke up the fire / And turn the roast around." Quoted after Camporesi, 25.

42. For the typology of the low-class braggart soldier in erudite sixteenth-century Italian comedy, see Fausto De Michele, Guerrieri ridicoli e guerre vere nel teatro comico del '500 e del '600 (Florence: Alma Edizioni, 1998), esp. 65-67 with reference to the braggart soldier and his relationship to the glutton on Della Porta's stage.

43. William Eamon, "Cannibalism and Contagion: Framing Syphilis in Counter-Reformation Italy," Early Science and Medicine 3.1 (1998): 12: "Acts such as this as expressions of hostility were a common feature of many popular uprisings in early modern Europe. During the Neapolitan insurrection of 1585, an angry 
physiognomonia, one of Della Porta's learned Latin works on physiognomy, the author quotes Firmicus Maternus's Matheseos, which contends that men with a belligerent nature (under the influence of the planet Mars) "eat a lot and digest raw meats and food that is not well cooked." ${ }^{4}$ This correlates with some of the more spectacular cooking recipes published in the Magia naturalis: as a special treat for parties, Della Porta gives detailed instructions on how to roast a turkey alive, in order to eat the animal before it is dead. ${ }^{45}$

We will return later to the issue of cannibalism; for the moment let us keep in mind that it constitutes a form of extremely transgressive behaviour that extends far beyond the limits of normative human behaviour. It is an act that combines both bestiality and gluttony.

\section{Physiognomonics and the monstrous}

According to Della Porta, eating habits are indicative of certain other habits also expressed in a person's physical appearance, the visible shape of which is influenced by food eaten and craved. This demonstrates yet another circular mode of reasoning that is characteristic of Della Porta's general intellectual outlook. ${ }^{46}$ Accordingly, his physiognomonics would seem to fit well with the

crowd eviscerated, killed, and mutilated the corpse of an eletto del popolo, Vincenzo Starace, whom the people held responsible for an intolerable increase in the price of bread. As a macabre and ironic climax to this grisly act of ritual murder, the crowd cut Storace's body into pieces, divided it among themselves, and ate the flesh." See also Panico, 132. On the historical context and veracity of this incident, see Rosario Villari, The Revolt of Naples, trans. James Newell and John A. Marino (Cambridge: Polity Press, 1993), 23-25 and passim. For Naples and the Italian south, see the acute analysis of ritual cannibalism during popular uprisings: Villari, 125, 131-32, 145. See also Sirri, Lattività teatrale, 164-65 with notes 6-7. On reports from the new Indies of cannibalism during the early modern period (Cabeza de Vaca, 1527), see Valentin Groebner, Ungestalten. Die visuelle Kultur der Gewalt im Mittelalter (Munich, Vienna: Hanser, 2003), 156-59. On the miller Menocchio's contemporaneous (and subversive) ideas about the commendable custom of eating the corpses of relatives in foreign lands and his idea that the fattest bodies were not only the most palatable but also most ethically opprobrious, see Ginzburg, 46-47.

44. Della Porta, Coelestis Physiognomonia, 46 (lib. 2, cap. 18): "multum comedentes et carnes crudas non bene coctas et cibos digerentes." My translation.

45. Giovan Battista Della Porta, Magiae naturalis, sive de Miraculis rerum naturalium libri IIII (Antwerp: Christopher Plantin, 1561), fol. 68r-v. (lib. 2, cap. 13) and Della Porta, Magia 1650, p. 494 (lib. 14, cap. 9). 46. On the reciprocal dependency of soul and body, see Giovan Battista Della Porta, De humana physiognomonia libri IV (Naples: Longus, 1602), 9-10 (lib. 1, cap. 2). 
well-known dietary regimes that constituted the core of Galenic medicine as taught at Renaissance universities. ${ }^{47}$

With this physiognomonic backdrop in mind, it is no surprise that on Della Porta's stage the glutton's wish to physically devour the objects of his desire is not without consequences. In order to better accommodate his enormous appetites, the glutton's abject craving makes him wish to change his own physical shape. Thus, the voracious parassita eventually cultivates a reciprocal relationship with the objects of his desire. A case in point illustrating this complex of ideas is a scene from the Trappolaria, where the glutton recounts a dream:

Tonight, I was dreaming that I was swimming in a sea of fat broth, and with every stroke I found ravioli and macaroni as wide and long as the length of a palm, which were sliding down from a rock of grated Parmesan cheese, from which, one after another, the waves were casting stewed capons, cooked turkeys with pieces of veal which were [as tender as] milk; and I, like a whale who gulps down ships, was gulping down veals, turkeys, and macaroni, always four at a time, like cherries. But alas, when I woke up, I realized that I had digested [everything] and that my stomach was as empty as an inflated bladder.

47. Della Porta, Physiognomia Humana, 45 (lib. 1, cap. 25): “Quod ex cibis quoque mores proveniant, Galenus retulit, verum nos plane intelligimus cibum quemlibet in ventriculam devorari primum, ubi prius confectus, mox per venas exceptus, humores in corpore efficit, ex quibus partes tum aliae omnes, tum simul cum iis cerebrum, iecur, ex eo aluntur. Id dum fit, calidiores, quam alias redduntur, tum frigidiores et humidiores, cum praevalentium humorum consimiles potestati fiant. Ergo nunc quoque, veluti respicientes ii, qui in alimenti hos modestiores fieri, illos proterviores, quosdam nequiores, alios temperatiores, et audentes et ignavos, et mansuetos, et lene et litigiosos, et pervicaces fieri posse aegre concedunt, et caetera." "Galen reports that all behaviour arises from the diet, and we can understand that food is absorbed by the stomach, where it is prepared before it is received by the veins, and brings forth the fluids (humores) in the body, from which then all the other parts, and with them also the brain (via the liver) are being fed. In this process, hotter foods are delivered more quickly, because as superior fluids they prevail over the other, colder and moister bodily fluids. We therefore can consider those who are more modest with regard to such (hot) foods, whereas there are also those are more reckless, more licentious, whereas others are more temperate, and daring or lazy, and tame, and gentle or quarrelsome, et cetera." My translation.) 
Questa notte, [...] mi sognava, che notava in un mar di brodo grasso, e che ad ogni bracchiata incontrava ravioli e maccheroni grossi e lunghi un palmo l'uno che sdrucciolavano giù da uno scoglio di cascio parmigiano grattuggiato, e di passo in passo l'onde buttavano capponi lessi, galli d'India cotti, con pezzi di vitelle che parevano di latte; ed io, come una balena, che tranguggia le navi, così tranguggiava vitelle e galli d'India, e i maccheroni a quattro a quattro, come ciregie. Ohimé, che come mi svegliai, mi trovai aver digesto e il ventre voto come una vessica gonfiata. (Trappolaria, 2.3 in Teatro, 2:257-58. My translation.)

The glutton dreams of being able to ingest enormous quantities of food; to that end, he imagines himself to be endowed with a monstrous body-that of a whale. Within this mode of circular reasoning, the gluttonous desire for food, along with the quantities eaten, entails an intrinsic urge to shape and reshape one's own body in ways capable of accommodating these extravagant preferences. (The glutton is thus a drastic exemplification of Della Porta's physiognomonics, just as physiognomonics highlights the proximity of the glutton to the animal world.) Della Porta, in fact, frequently represents the parassita as wishing to become a monstrous mixture of different animals:

Why couldn't I have been designed with a wolf's hunger, a frog's mouth, a toad's stomach, a crane's neck, a shark's teeth, a snake's forked tongue, an ostrich's stomach, a horse's thirst, a dormouse's slumber, and a cow's capacity to shit? (Sister, 97$)^{48}$

Non poteva la natura farmi una bestia come queste? Darmi fame di lupo, bocca di rana, pancia di rospo, collo di grue, denti di cangnesca, due

48. For another example, see also Furiosa, act 3, scene 4 (Teatro, 4:151), in which this time the glutton Lupo ("Wolf") speaks: "O Dio no potrei esser quel can a tre bocche che sta nell'Inferno per tracannarti con tre bocche? Non potrei esser bue o pecora che, dopo averti mangiata ed inghiottita, ne rivocasse nella gola e ti ruminasse tre altre volte? Per che non fui rospo o ranocchia, che fussi tutto gola senza spalle, senza petto e tutto corpo come un saccho?" ("Oh God, could I not be that dog with three mouths that is in Hell, in order to be able to devour you with three mouths? Could I not be an ox or a sheep so that, after having eaten and swallowed you, I could bring you back in my throat and ruminate you three more times? Why can't I be a toad or a frog so that I could be all throat without shoulders, without chest, and my whole body like a sack?" My translation.) 
lingue de serpe, stomaco di struzzo, che bevesse come cavallo, dormisse come ghiro e cacasse come una vacca. (Sorella, 2.1 in Teatro, 3:152)

To make a long story short, the glutton wishes to fare l'amore (make love) with animals because he wants to become an animal himself. Of course, ever since Homeric times and the story of Circe, banqueters have often been depicted as assuming bestial shapes. ${ }^{49}$ And certainly Della Porta's audiences were familiar with many grotesque representations of the gluttonous body: for instance, in Andrea Alciato's enormously influential Emblematum liber, one illustration on gula (appetite) shows a male figure with a bird's throat and a huge pot belly, holding in his hand what the epigram describes as a ravenous bird (Figure 1). ${ }^{50}$ The idea that the glutton's appetite actually points to bestial habits of desire is also present in the Emblematum libellus, in which one finds an illustration of a young man in front of a door holding a plate of crabs in his hands: the text explains that these animals are the perfect gift for a glutton because the physical shape of river-crabs constitutes a fitting parallel to the parassita's inhuman habits (Figure 2). ${ }^{51}$

Receive these river crabs which we present to you. These gifts match your character. They have watchful eyes, and a great row of claws armed with a pincer, and a huge gut is there. You too have a protruding belly with fat paunch, scuttling feet and sharp weapons on them, as you hang about the crossroads or move among the seats at table, and maliciously shoot your stinging, witty jibes.

Quos tibi donamus, fluviales accipe cancros, / Munera conveniunt moribus ista tuis. / His oculi vigiles, \& forfice plurimus ordo / Chelarum

49. On the uses of this metaphor in early English literature see Williams, 1:67-68.

50. Andrea Alciati, Emblemata Andreae Alciati (Lyon: Guillaume Roville, 1548), fol. 74r "Gula: Curculione gruis tumida vir pingitur alvo, / Qui Larum, aut manibus gestet Onocrotalum. / Talis Forma fuit Dionysi, et talis Apici, / Et gula quos celebres deliciosa facit." ("We have here painted a man with a crane's long gullet and a swollen belly, holding in his hands a gull or pelican. Such was the form of Dionysius, such the form of Apicius, and all those whom gourmet taste makes famous.") The English translations are from the wonderful Alciato at Glasgow website (http://www.emblems.arts.gla.ac.uk/ alciato/index.php); see same for a detailed commentary on the persons mentioned in the text.

51. Alciati, fol. 76r. 
armatus, maximaque alvus adest: / Sic tibi propensus stat pingui abdomine venter, / Pernicesque pedes, spiculaque apta pedi. / Cum vagus in trîviis, mensaeque sedilibus erras, / Inque alios mordax scommata salsa iacis. (Alciati at Glasgow)

Alciato's representations of gluttons with extended necks and the physical attributes of ravenous birds or greedy (but delicious!) crabs are, however, rather harmless when compared to the gluttons on Della Porta's stage with their monstrous bodies. ${ }^{52}$ Again, one might perceive Della Porta's grotesque figures merely as part of the apparatus of the mannerist stage or as the expression of Della Porta's taste for the macabre and the grotesque with a baroque penchant for the hyperbolic. I believe, however, that the situation is more complex: what occurs in Della Porta's literary imagery dovetails with a larger setting, namely with the ideas reflected and echoed in Della Porta's ostensibly erudite "scientific" books on physiognomonics and on natural magic. The compelling nature of this correspondence is by no means surprising, for Della Porta's numerous works on the scienza of physiognomonics are renowned through the present day. The identification of visible animal traits in order to assess hidden bestial habits (brutorum inclinationes) in human individuals is the central aim of Della Porta's scientific works, ${ }^{53}$ which tend to naturalize human beings by using a science that constructs a metonymic relationship between animals, plants, human beings, and the stars. The glutton's fantasy of changing the shape of his body in order to accommodate his insatiable appetite-that is, his inclination towards bestiality-therefore allows for yet another perspective on his persona: from the point of view of physiognomonist theory, his abysmal

52. Such verbal representations of gluttony are not foreign to the contemporary stage. For instance, Giordano Bruno, Kerzenzieher/Candelaio, trans. and ed. Sergius Kodera (1582; Hamburg: Meiner, 2013), 86-88, provides a description reminiscent of the physical appearance of Della Porta's gluttons, though in the Candelaio the context is different: the body of the glutton is presented through the literary form of a poem composed by an ignorant schoolmaster who, in his inept verses, blindly raves against one of the most positive figures of the comedy. On visual representations of gluttons' grotesque bodies in sixteenth-century French literature, see Katja Gvozdeva, "La procession charivarique en texte et image: Le recueils lyonnais de la chevauchée de lâne — La Nef des fous de Sebastian Brand — Le Quart Livre de Francios Rabelais - Les songes drolatiques de Pantagruel," in Medialität der Prozession. Performanz ritueller Bewegungen in Texten und Bildern der Vormoderne, ed. Katja Gvozdeva (Heidelberg: Winter, 2011), 331, especially fig. 8, with reference to Les songes drolatiques de Pantaguel (Paris, 1565).

53. See for instance, Della Porta Physiognonia humana, 10 (lib. I, cap. 2). 
manners and his desire to have sex with animals-even to become an animal himself-function as a hyperbolic confirmation of the principles of this science. This science, moreover, did not merely describe but also offered recipes for the improvement of the body. Della Porta thus purports to be in the position of being able to change, by natural means (such as surgical interventions or dietary regimes), the bodies of human beings and thereby also to change their habits and inclinations.

\section{Punishment and medicine}

It seems that Della Porta hoped to demonstrate that he was capable of identifying undesirable individuals with, for instance, bestial inclinations and that he could transform and police their abject bodies. He thus aimed towards the artificial improvement of the individual through the correction of its outward appearance, employing drastic methods such as physical intervention into the body. ${ }^{54}$ Take the following example from Sorella:

We will tie you up in a basement chamber [...] and we will give you ten enemas per day, in order to empty your bowels well, and then we will hang you with your feet up, until you vomit what you have eaten in this house; and then we will give you two slices of bread and one cup of water per day.

Farti ligar in una camera terrena. [...] E farti dieci crestieri il giorno, accioché evacui bene; poi attaccarti con i piedi in su, finché vomiti quanto hai mangiato in casa sua; poi darti due fette di pane il giorno e un becchiero d'acqua. (Sorella, 2.3 in Teatro 3:157. My translation.)

With this "scientific" physiognomonic context in mind, it comes as no surprise that Della Porta's glutton, with his bestial sexuality, frequently becomes the object of treatments we would today term sadistic, such as lethal slimming diets and other drastic means of curbing execrable appetites; ${ }^{55}$ thus a parassita may

54. Sergius Kodera, Disreputable Bodies: Magic, Gender, and Medicine in Renaissance Natural Philosophy (Toronto: Centre for Reformation and Renaissance Studies, 2010), 251-73.

55. See for example Olimpia, 5.3 (Teatro, 2:83): "Così cotesto stomaco ti sia aperto ed a cotesta gola ti sia posto un capestro dal boia, che non mangi né bevi più mai, [...]." ("And so your stomach will be opened, and the hangman will put a string to around your throat so that you will never eat or drink again [...]." 
also fall victim to various practical jokes. In Magia naturalis, for instance, Della Porta recommends a recipe to quench the glutton's hunger: by administering him a glass of wine mixed with belladonna root, after a few hours the potion will paralyze the throat to such an extent that the person under its spell will be able neither to eat nor to drink, thus temporarily starving him-and, by extension, effectively subduing his monstrous inclinations. It goes without saying that, as a cunning natural magus, Della Porta also knew how to lift that spell at willby making his victim drink a glass of milk or vinegar. ${ }^{56}$ Such minor and cruel experiments have an educational purpose, of course, and serve Della Porta by demonstrating his unlimited command over the human body (especially the bodies of other people) and its more abject inclinations. In analogous ways, Della Porta's comedies betray a characteristic inkling for the sadistic delights of drastic physical corrective measures. Much as in today's popular medical discourses, gluttony is staged here as a medical problem:

Trinca: Gulone is like cancer: the more you feed him the more [cankerous and fistulous he becomes].

Pardo: So what's the best cure?

Trinca: Just what they use for syphilitics: a forty-day diet of bread and water, [which cures his hunger and thirst to his bones]. (Sister, 94)

\footnotetext{
My translation.) Olimpia, 1.2 (Teatro, 2:19): “[...] una infermità che si chiama lupa che dà una fame tanto affamata che quanto più mangia più s'affama. [...] né tutti i sciroppi, medicine o servigiali del mondo non la possono cavar fuori." “[...] an ailment that is called wolf (lupa) which gives you such a starving starvation hunger that the more you are eating, the more you are starveing [...] [a sort of hunger] which all the syrups, medicines, and cures in the world are incapable of expelling from the body." My translation).

56. Della Porta, Magia (1650), 501-02 (lib. 14. cap. 13): “Quomodo a mensis magnatum parasiti et gnatones arceantur. Haud levi artificio a notris mensis et magnatum coenipetae et gnatores fugabis, nec parum propterea glandii et alacritatis nostri convivis adjicietur. [...] Nos ita saepissimae facere consuebimus. Herbae, bella donna vocatae, radicis drachmam unam ... vini phialam immergimus. [...] Si vis gargarizanthum absorbebat prandeat bibatque lactis, aut aceti, plusculum reddet eum ac si nihil unquam passus fuerit." ("How to drive Parasites and Flatterers from great mens Tables: It is an easie matter to drive away from your Tables and great men's tables, all smell-feasts, and cogging foisting fellows, and this will make our guests very cheerful and glad. [...] I have done it oft-times: I infused in a glas of wine one drachm of the root of an herb we call Belladonna [...] If you would have him eat or drink, let him gargle a good quantity of vinegar in his mouth, and he will be as if he had suffered nothing." Translation from Della Giovan Battista Della Porta, Natural magick (i.e., anonymous English translation of Della Porta, Magia (1650)] (London: 1658) [Anastatic reprint: New York: Basic Books, 1957], 326.)
} 
Trinca. Gulone è come il canchero che, quanto meglio lo nudrite, piú incancherisce e infistolisce.

Pardo. Che rimedio ci sarà?

Trinca. Quello degli infranciosati: con una dieta di pane e di acqua per quaranta giorni, ché lo consumi la fame e la sete in fin all'ossa. (Sorella, 1.5 in Teatro, 3:159-160.)

Note that the treatment for gluttony is the same as for a venereal disease, which again highlights the idea that gluttony is an indication of a sexually deviant personality. For ordinary lovers, Della Porta has similarly cruel treatment in store. For him, "love" is always "besotted"; it is a somatic phenomenon caused by an imbalance of the humours, and infatuation can be (and indeed often is) medicated by drugs. Emblematic of this practice is an oft-repeated joke, voiced by a witty servant and addressed to the innamorato (who is raving with love): "Pigliate silopi e medicine che vi purghino il corpo;" "Take syrups and medicines that might purge your body," Sorella, 1.1, Teatro 3:130. My translation.) In La furiosa (1609), a doctor meticulously describes (and orders) similar drastic cures for a lover:

The cases of the aberrations caused by love are not as hopeless as you say; and when cures by means of hard work, fasting, and vigils have been unsuccessful, I can cure the mind perfectly with one of my wonderful medicines in the wink of an eye. I will give only a couple of pills [of hellebore, a strong emetic, to the patient] by means of which I make him vomit all the choleric [humor] that has arisen in his body. ${ }^{57}$

Le spezie delle svanie amorose non son così disperate come voi dite; e per esserne state di fresco, per fatiche, digiuni, e vigilie, con un mio mirabil rimedio mi basta l'animo curarli perfettamente in un subito. Darò due sole pilole [di elleboro] per uno che gli farò vomitar tutta la colera nera che han conceputa nel corpo. (Furiosa, 3.3 in Teatro, 4:148)

57. In case lovers resist treatment, they have to be forced: Furiosa, 3.3, Teatro, 4:150: "in tal caso la medecina è il bastone." ("in this case the medicine is the club." My translation.) See also Olimpia, 4.10 (Teatro, 2:76, my translation). 
After the hellebore is (forcibly) administered to the innamorato, the doctor has yet another ordeal in store for his lovesick patient: he is to be tied up, locked in a dark room, and treated with enemas. ${ }^{58}$ To be sure, these cures for love-sickness seem completely over-exaggerated and the physical violence perpetrated on the ardent lover is depicted in hyperbolic form. Or so one might think. If we stop to consider that medieval and Renaissance doctors prescribed exactly such remedies for patients suffering from amor hereos, however, we may be less sure that Della Porta's treatments constitute hyperbole. ${ }^{59}$

Della Porta's grotesque ways of representing the power of emetics over our emotional lives point to the idea that meraviglie, like iconic beauty and besotted love, elide verbal negotiation; they are natural forces just like the glutton's inclination towards bestiality. According to Della Porta's Celeste fisiognomia, one of his most important texts, these traits are caused by an imbalance of the medical humours, therefore, they cannot be corrected either through learning or by the cultivation of spirituality. ${ }^{60}$

58. Furiosa, 4.6, Teatro, 4:162: "Dateli delle pugna [...] Togliete questo miseraccio e così ligato, portatelo in cantina. Serrate le fenestre, che stai al buio, che così iI meno gli svaria il cervello. E quivi, così legato, fategli duo cristieri che ho ordinati, che da sopra e da sotto purghi i maligni umori."

59. See, as one locus classicus from 1303-05, Bernard Gordon, Lilium medicinae, de morborum proprie omne curatione (Lyons: G. Rouillius, 1559), 210 (ch. 20): "Amor qui hereos dicitur, est solicitudo melancholica propter mulieris amorem" ("The love called heroic is a melancholic anxiety caused by love of a woman," my translation), which gives drastic instructions to cure this ailment.

60. Della Porta, Coelestis Physiognomonia, fol. 228v (proemio to bk. 6): "Gia nei libri passati sè abondevolmente dimostrato, come da segni del corpo si possino costumi riposti ne' più segreti luoghi dell'animo investigare veramente cosa assai degna, \& ammirabile, resta che $[\ldots]$ si tratti di cosa più mirabilissima, [...] cioè che conosciuti i tuoi, ò gli altrui vitij, possi levarli via, e scancellarli del tutto. A che dunque ci gioverìa questa arte, se conosciuti i tuoi defetti, non potessi quegli convertirli in virtudi? Ma ciò non con pensieri, imaginationi, ò persuasioni di morali Filosofi, che per lo più vane riescono, ma con purgationi, locali rimedij, e natural virtù di herbe, pietre, \& animali \& occulte proprietadi. [...] Perciochè l'habito dell'anima potersi mutar con diligentia dice esser cosa chiara, con cibi, con bere, \& con essercitij mutar il temperamento in meglio." ("As we have already shown at large in the preceding books how one may discover the deepest secrets of the mind from the signs of the body, and that this is a truly dignified and admirable thing, now it remains to discuss a most admirable thing, [...] that means, once you become familiar with your own vices or those of others, you also become capable of removing and totally obliterating them. For what would be the use of this art, if you could know your defects, but were incapable of changing them into virtues? But this is not done through thoughts or imagination, or the arguments of moral philosophers, which are for the most part vain, but rather with purges, local remedies, and the natural virtues of herbs, stones and animals, and the occult properties [of 


\section{Syphilis and cannibalism}

With the broader context of physiognomony in mind, we are now in a position to turn the kaleidoscope of Della Porta's ideas about bestiality once more in order to look at the close relationship between bestiality and cannibalism. We should first recall that the glutton seeks to devour the objects of his desire and that some of these are human beings. We have seen that Della Porta represents the glutton as the grotesque embodiment of a disease. The river crabs (canceres, which in Alciato were gifts that should remind the glutton of his repulsive habits) are transformed in Della Porta into the embodiment of a terminal illness. Interestingly, however, the recommended therapy for the glutton is not the same as that for cancer, as in the above quotation. Instead, the treatment is the same as for a contemporary pandemic, syphilis-a sexually transmitted disease. This again points to the deep connection between sexual transgression and the abnormal craving for food, as we shall see in a moment; for the emergence of syphilis was associated with cannibalism. The first outbreak of syphilis in Europe occurred in Della Portas hometown of Naples during the city's brief conquest by French troops in 1494-which is why it was named the mal di Napoli. ${ }^{61}$ Syphilis was immediately associated with visible deformities of the skin and with hair loss. These alterations, we might suppose, would have made syphilis into a textbook case for the science of physiognomonics: the patient's horrible blemishes and ulcers served to prove conspicuously that repulsive physical features were the outward expression of an individual's lustful inner inclinations. ${ }^{62}$

In this context, it is noteworthy that a renowned practitioner and theorist of medicine, Leonardo Fioravanti (1517-83 or later), did not believe that the

these things]. [...] Because it is clear that the habits of the mind can be changed with diligence, by means of food, drink and exercise we can ameliorate the temperament." My translation.) For further discussion of this passage, see Kodera, Disreputable Bodies, 263-65.

61. For a general introduction to this topic, see Jon Arrizabalaga, John Henderson, and Roger French, The Great Pox: The French Disease in Renaissance Europe (New Haven and London: Yale University Press, 1997); Anna Foa, “The New and the Old: The Spread of Syphilis 1494-1530," in Sex and Gender in Historical Perspective, ed. Guido Ruggiero (Baltimore: Johns Hopkins University Press, 1990), 29-34; Eamon, 1-31; Laura J. McGough, Gender, Sexuality, and Syphilis in Early Modern Venice: The Disease that Came to Stay (New York: Palgrave Macmillan, 2011).

62. As Eamon writes, "The examples of plague and leprosy suggest another role for disease in human culture: it helps frame debates about society. The disparity between sickness and health that illness punctuates provides a ready metaphor for the perceived gap between what is and what ought to be" (2). 
mal di Napoli was a new disease. He was convinced that syphilis originated from cannibalism. In his very popular Capricci medicinali (1561), Fioravanti contends that during the siege of Naples in 1494, sutlers had served human meat to the soldiers on both sides. Because the meat had been disguised and marketed as a fancy local speciality, the starving soldiers devoured great quantities of it. (This gruesome story is, of course, eerily reminiscent of the glutton's cannibalistic desires as well as of the braggart soldiers' eating habits on Della Porta's stage.) Moreover, Fioravanti writes in the second book of his Magia naturalis (1589) that he has tested the veracity of his theory on animals in ways paralleling Della Porta's experiments. He nursed two suckling pigs, a bird of prey, and a puppy solely on the meat of their respective species, and they all quickly developed the same ailment: the ulcerated skin that was the characteristic symptom of syphilis. In short, Fioravanti believed that the mal di Napoli originated from unnatural and sinful behaviour-eating the flesh of one's own species-an aberration that left visible marks on the body. ${ }^{63}$ From the perspective of physiognomonics, syphilis is thus a perfect example for proving the theory that abject sexual desires lead to monstrous deformations of the body. Fioravanti's topics of savoury dishes, starvation, and cannibalism in conjunction with illicit sexual behaviour are negotiated on Della Porta's stage through the persona of the glutton with his monstrous desires. In this context, it is also vital to keep in mind that, as Liliequist has noted, there is

an implicit analogy between bestiality and cannibalism: making love to a beast is like eating human flesh. This correspondence reveals an essential meaning of bestiality, as it implies not only moral corruption and foolishness but a defilement in the most physical sense. [...] The correspondence of cannibalism consisted in the supposed mixture of human and animal seminal fluids, resulting in a commixtio sanguinis. ${ }^{64}$

This mixture of fluids works both ways: it not only dehumanizes the perpetrator of bestial acts, but also transforms the victim into a human being. When viewed from this perspective, the glutton on Della Porta's stage becomes an

63. Eamon, 9-11, 23: "[Foriavanti] was unable to see cannibalism as a cultural practice, i.e., as behaviour that gives meaning to the world. To him cannibalism is intelligible only as a culinary practice, one that violated universal laws of proper eating."

64. Liliequist, 404-06 and 408. 
embodiment of the notion that the essence of human beings tends towards the undetermined, the malleable, and the animal. The fantasy of an individual's boundaries as porous also evokes the idea that bodies can be manipulated at will, which implies the physiognomonic phantasma of total control. This complex of ideas is grotesquely enacted on Della Porta's stage and is perhaps best captured in the following monologue by one of his imaginary creatures. In the Sister, the Glutton raves against nature and fantasizes about having not only an endlessly long throat, but a direct hole in his abdomen that can be opened and closed in order to better accommodate his voracious appetites:

Nothing but big words from these sages. When I hear that nature has been a benevolent mother, I say let all philosophers perish and their whole breed with them who say so. [...] I figure that if nature made us the way we are, she's our greatest enemy. [...] With such a little pipe you can't swallow fast enough before hunger comes over you as if you hadn't touched a bite. We should have a gullet a mile long so that food takes a whole day to reach the stomach, and the guts should be very short, I say, a passage wide open from mouth to arse to expel in a jiffy what's just taken in. And why this huge corpus with arms, legs, and head and such a diminutive stomach? [...] How frustrating to find oneself in front of a table piled with all manner of food and wine and have no stomach to store it. It makes me so enraged that I could slit my own bread-basket with a knife to go on stuffing it non-stop. Or at least a slit in the belly with buttons to open and close like a shirt; in times of surfeit or pain we could open it, take a peek in, and then shut it up again. It's the oxen, the goats and the birds that nature has been kind to [...]. (Sister, 96) $)^{65}$

Sempre ch'odo sputar filosofia da questi savioni, odo dir che la natura è stata a noi benignissima madre. $\mathrm{O}$ che mai nascessero più filosofi $\mathrm{e}$ che

65. See also Olimpia, 4.4 (Teatro, 2:49), where the glutton Mastica (“Chew") says: "O Dio, potessi allargarmi questo ventre altro tanto per verso, spalancarmi questa bocca, accrescermi un altro filaro di denti, allongarmi questo collo, che se mai fui Mastica ci serò questa sera, che non cessarò di masticar mai finché non toccherò con le dita che son pieno fin alla gola." "“Oh God, greatly enlarge my belly for me from the back, open my mouth, endow me with another row of teeth, extend my neck, [...] because if ever I was Mastica, I shall be him this evening, for I will never stop chewing until I can feel with my fingers that I am full up to my throat." My translation.) 
si perdesse in tutto il collegio e la razza loro: perché quando discorro fra me, trovo tutto il contrario, che la natura ci è stata capitalissima nimica nel farci del modo che ci ha fatto. [...] ch'appena mangiato un boccone, cala giù, sparisce subito, come se mangiato non l'avesti. Doveva far il gargarozzo lungo un miglio, che, calando giù per quello il cibo, durasse il diletto tutto un giorno; e le budelle far tre diti, dalla gola al buco di sotto, largo ed aperto, che subito inghiottito uscisse fuori e fusse l'introito uguale all'esito. A che proposito consumar tutto il corpo in gambe, in braccia e testa, e 'l ventre farlo picciolo? [...] Che dispiacer si trova uguale a quello che di trovarsi ad una tavola abondante e ben fornita di vivande e di vini eccellentissimi, poi aver un corpo picciolo e non poter divorare? Che tanta è la rabbia e la disperazione, che vorrei allora con un coltello forarmi la pancia per poterlo cavar fuori e tornare a riempirlo. Almeno ci avesse una apertura nel ventre che si aprisse e serrasse con bottoni, come le vesti, che dolendoci il ventre o essendo troppo pieno, potessimo guardar che cosa sia dentro e poi tornar ad affibbiarlo. A me par che sia stata benignissima madre agli animali, perché ha fatto al bue, alla capra e agli uccelli una saccoccia alla gola che 'l cibo ingoiato si riceve in quella, e dopo mangiato ruminano quel cibo, e mangiano di nuovo, e si trattengono tutta la notte. (Sorella, 2.1 in Teatro, 3:151-52.)

Again, this mode of speech is aimed at creating the highest possible peripety: the Glutton becomes a monstrous tableau vivant, allowing Della Porta to display his macabre physiognomonic fantasy. The Glutton's wish to transform his body in order to better accommodate his abject desire for food is, moreover, a farcical echo of a key tenet of Neoplatonic metaphysics according to which the soul forms the body it inhabits - an idea fundamental to the theory of erudite Renaissance magic that was embraced by Della Porta in his Magia naturalis. ${ }^{66}$

66. Giovan Battista Della Porta, Magiae naturalis, sive de Miraculis rerum naturalium libri IIII (Antwerp: Christopher Plantin, 1561) fols. 4r-5r (lib. 1, cap. 4). In Della Porta’s De physiognomia humana, 43 (lib. 1, ch. 24), the situation is more complex: here the soul forms a body that is already prepared physically by the temperaments: "Anima igitur in corpus descendens, illud animat, et secundum corporis temperamentum operatur, quia temperamentum sibi instrumenta paravit, unde alii feroces, magnanimi, et alii inertes, et timidi evadunt. Ex hoc temperamento nascuntur morum varietas [...]." ("And as the soul descends into the body, it animates it, and operates according to the body's temperament, because it produces instruments for itself, which is why some become ferocious, others magnanimous, and others weak and timid, and from this temperament the variety of different characters arises [...]." My translation.) 


\section{Conclusion}

The glutton's fantastic wish to be able to open his belly at will represents his desire to assume bestial and monstrous shapes in order to both express and alleviate his extraordinary psychic and physical disposition, and indicates his abject sexual inclination to have sex with animals. His wish also expresses a specific longing to control his body in ways grotesquely reminiscent of surgical interventions. In this way, the glutton acts as a mouthpiece for Della Porta's own exaggerated claims of his capabilities as an experienced natural magus, in a kind of science fiction ante litteram. The grotesque body of the glutton thus becomes, for Della Porta, a site of demonstration for his ability not only as a playwright but also as a natural magus, in that he arrogates to himself the potential to produce bodies that are sources of marvel paralleling the histrionic peripety of his works for stage. ${ }^{67}$ Della Porta's attitude towards these practices remains highly ambivalent, for as a magus who sought to control natural processes he was interested in producing monsters by means of crossbreeding. In the Magia naturalis, Della Porta thus supplies us with technical descriptions for crossbreeding human beings with animals; for instance, he mentions the possibility of a pairing between a man and a female donkey.$^{68}$ As Liliequist amply

\section{See Kodera, "Histrionic Science."}

68. See Kodera, "Humans as Animals," 109-15; Della Porta, Magia (1650), 76 (lib. 2. cap. 12): "Sed hoc [scil. ut ex homine et a infantes nascere] videtur Galeno impossibile, et Naturae, quum mistio sit animalium differentium: neque enim si coitus homini cum equa fiat, recipiet matrix sperma, quum longiori pudendo opus fuerit, et si quando superet, corrumpet utique, vel mox, vel non multo post. Et si in conceptu misceretur, et perficeretur hoc animal, quib. nutrimentis nutriretur iam natum? Sed mihi non impossibile videtur, etsi difficile, quum non aeque omnes, et homines eadem complexione constent, sed possibile reperiri homines equinae complexioni similes aliquantulum, et sunt etiam qui longiori pudendo fruantur, et sunt inter equas, quae breve matricis collum habeant: et fortasse aliqua coelesti influentia semina animata concipiant, et partum ad debitum tempus producant. Haec quia rarissime congruunt, rarissime eiusmodi partus videntur." ("But Galen cannot think this possible, nay, it is scarce possible in nature, seeing a man and an ass differ so much as they do. For if a man should have to do with an Ass, her womb cannot receive his seed, because his genitories are not long enough to convey it into her place of conception. Or if it were, yet she would presently, or at least no long after, mar his seed. Or, if she could so conceive, and bring her birth to perfection, how, or by what food should it be nourished after birth? But, though can hardly be, yet I do not think it altogether impossible, seeing all men are not of a like complexion, but some may be found, whose complexion does not much differ from Horses, and some men also have longer and larger genitories then others have, as also some mares and asses have less and shorter genitories then other have. And it may be too, that some celestial influence has a stroke in it, 
documents, such bestial pairings seem to have been a very real preoccupation, at least among the uneducated of early modern Europe:

[T]he ultimate fear and consequence of this transgression and mixing of categories was not defilement and bodily corruption but the possible monstrous offspring. [...] a young servant confessed that he did not dare to leave his semen in the mare, considering it most shameful if the mare should give birth to "something resemblant to himself." 69

As opposed to earlier authors such as Rabelais, who (at least in Bakhtin's influential reading) celebrates the body, the subversive culture of laughter, and the unlimited fertility of nature through descriptions of the grotesque bodies of gluttonous giants, it is obvious that, for Della Porta, people who diverge from the standard of the mean are dangerously threatening: their abnormal shapes and monstrous appetites betray a deviant sexuality. Even though gluttons appear as grotesque sources of peripety on Della Porta's stage, their deviant bodies and abject sexual inclinations are held in check by drastic methodsan early form of, in a Foucaultian sense, "policing" the body. To be sure, the persona of the glutton and his enormous craving for food has a decidedly theatrical character. Yet Della Porta's fascination with monstrous bodies and their concomitant bizarre sexual desires also betrays a tendency to understand human beings increasingly as akin to the animal world and indicates the

by enlivening the seed, and causing the Dam to conceive it, and bring it forth in due time. And because all these things do very seldom concur together, therefore such births are very seldom seen." Translation from Della Porta, Magick, 42- 43.) This passage is an elaboration of Aristotle on crossbreeding, De generatione animalium $4.3,769 \mathrm{~b}$.

69. Liliequist, 408. On the increasing belief in the real existence of such hybrid animals in the later Middle Ages, see Salisbury, 139 and 147. On the gendered side of this issue, Salisbury says that during the late Middle Ages, "[...] associations linking women and animals continue with increasing frequency. [...] the fourteenth century Spanish Book of Good Love further develops the comparisons between women and animals in similes in order to explain how one should treat women. Women were like horses, so they should be forced into sexual intercourse; women were like hares, who get confused when hunted. Juan Ruiz, the author of the Book of Good Love, went beyond similes in his description of bestial women. He described a 'mare' girl in detail, and his description shows the blending of human and animal that characterized this woman, this lower-class woman. [...] He was obviously playing with the notion that intercourse with this creature was bestiality, and he shows how quickly and easily women could be reduced to the animal world" (157). 
porosity of boundaries between these two spheres of human and animal. We have seen that syphilis, a disease associated with promiscuous sexuality, was also associated with a sacrilegious ingestion of human flesh; how, in turn, cannibalism and bestiality were seen as related phenomena. In this way, too, human beings and animals come closer together; animals might appear as human and vice versa. The naturalization and demystification of sexuality that follows from this conflation of human and animal grotesquely eclipses the ancient metaphoric use of intercourse (especially in the biblical sense of "defloration" and "to know") as a tool of a purportedly "higher" or even divine knowledge. Bestiality thus becomes a vehicle for voicing a potentially dangerous but nevertheless spectacular urge to modify one's own body (or that of others).

The ensuing categorically sensual and somatic foundations of all human experience seem to be a strikingly cohesive thread along which large portions of Della Porta's mannerist early modern literary and scientific texts gain their coherence-a coherence, of course, that is based on circular reasoning. This way of reasoning is reflected in the kaleidoscopic sequence of monstrous and grotesque images which Della Porta uses to connect the excessive craving of food with the desire to have sex with animals; with the glutton's wish to transform his body into that of a monstrous animal in order to accommodate his insatiable and abject appetites; with physiognomonics and the playwrightmagus's claim that he could not only detect but also eradicate such inclinations by physical means in both the theatrical and natural worlds. 


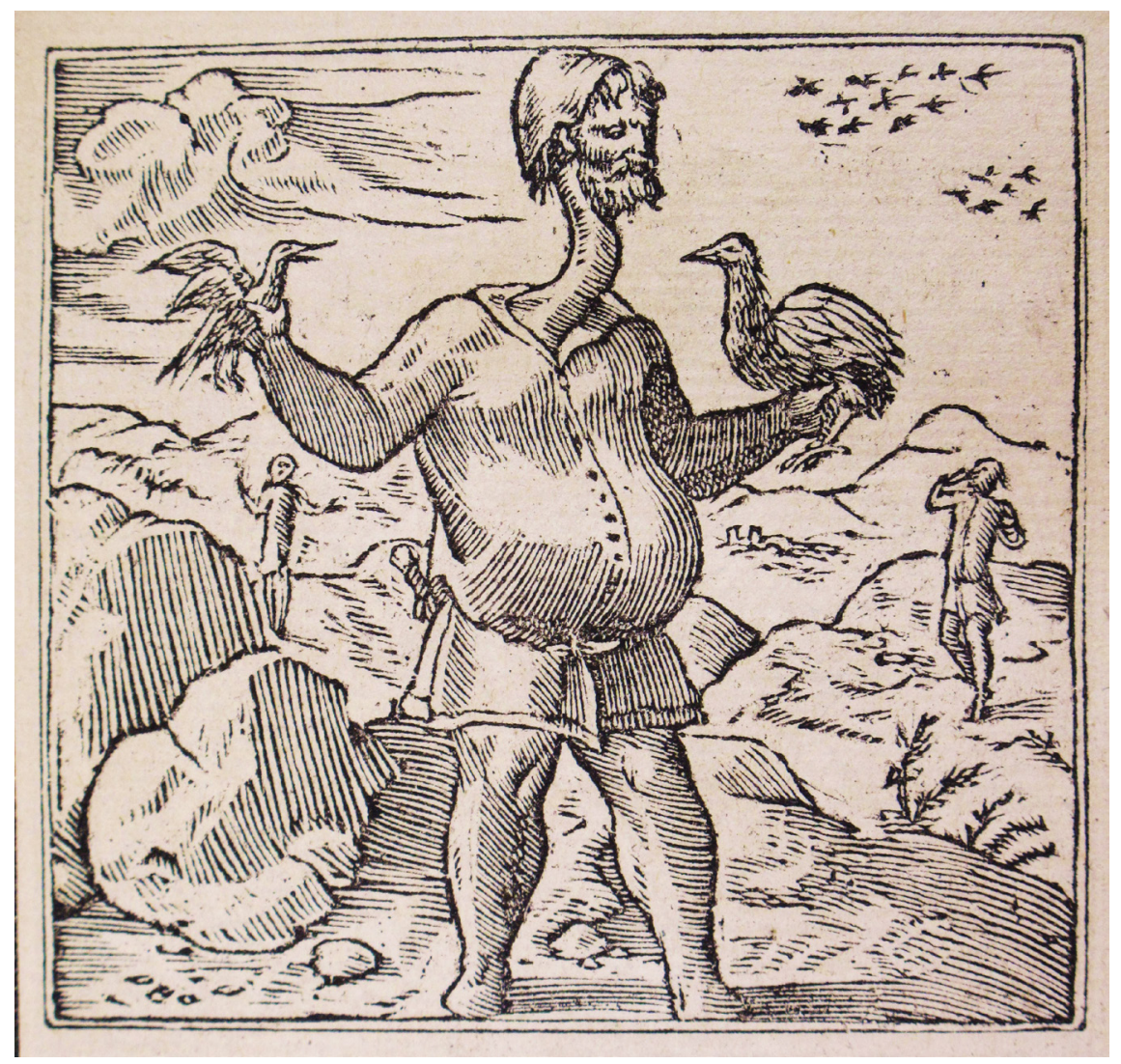

Figure 1. Alciati, Andrea, 1492-1550: Emblemata Andreae Alciati. - Lugduni: apud Gulielmum Rovillium, 1548, fol 74r. Universitätsbibliothek Wien, University of Vienna. 


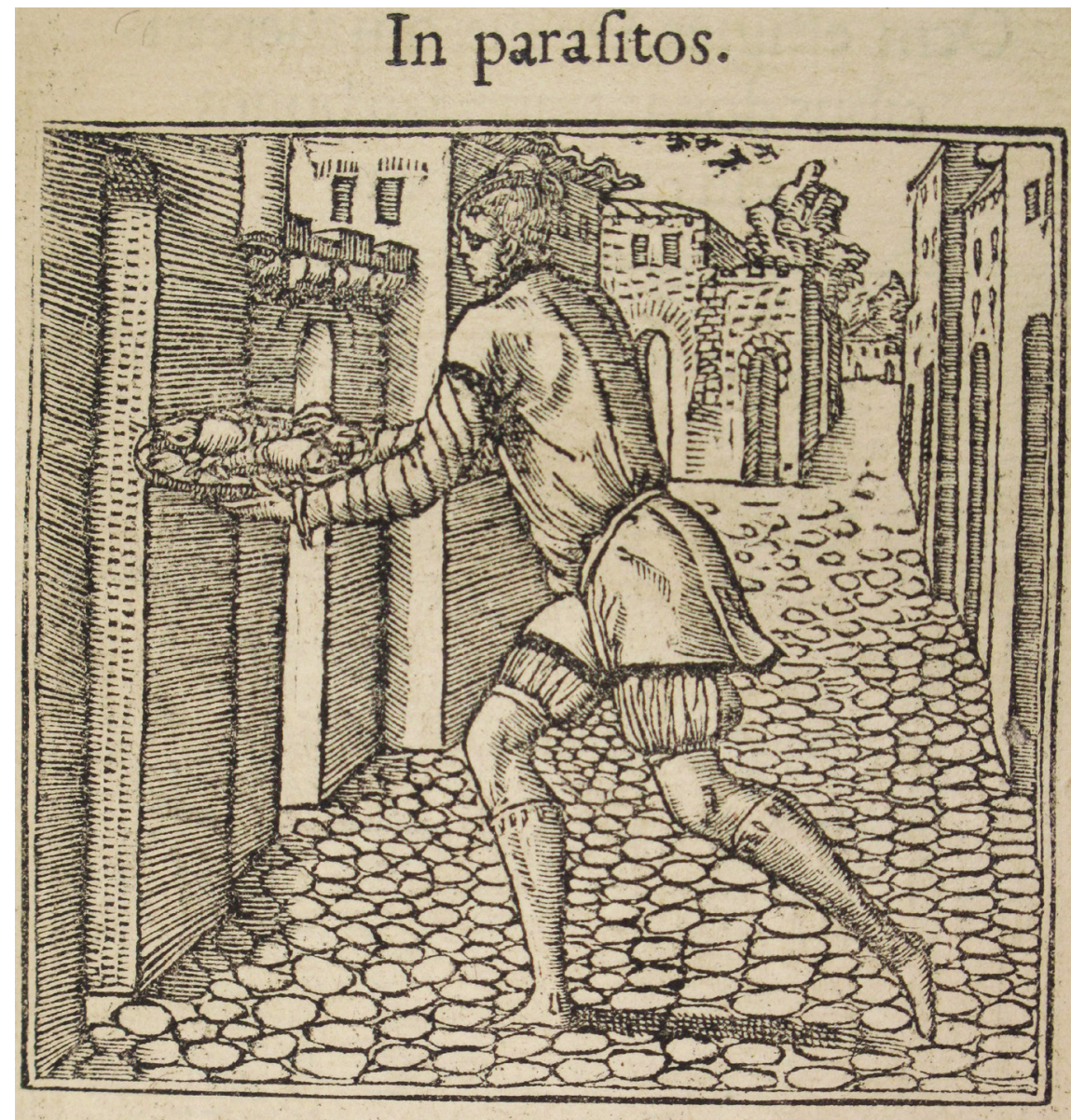

Figure 2. Alciati, Andrea, 1492-1550: Emblemata Andreae Alciati. - Lugduni: apud Gulielmum Rovillium, 1548, fol 76r. Universitätsbibliothek Wien, University of Vienna. 
